\title{
On the Real Nature of Vital Staining.
}

\author{
Bs \\ Kunio Sato. \\ From the Institute of Anatomy Okayama University. \\ (Director: Prof. K. Kōsaka).
}

With 6 Text Figures.

Contents.

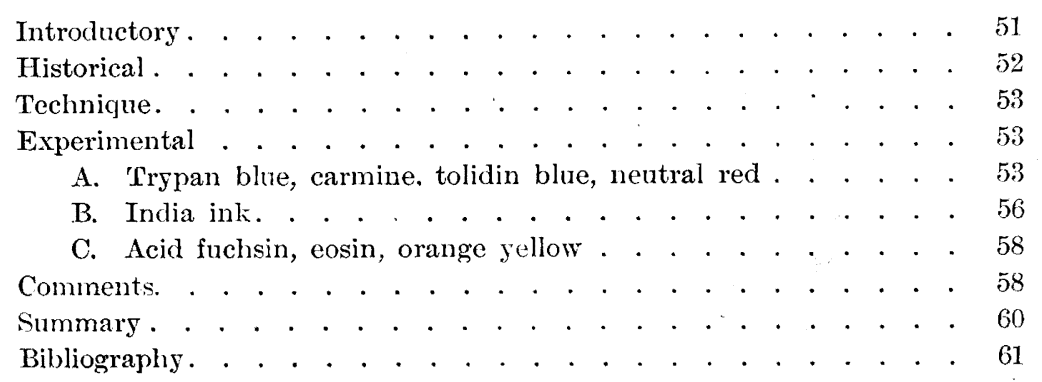

\section{Introductory.}

In recent years the employment of various colloidal suspensions as a method of 'vital staining' has become so prevalent that it is hardly necessary to give general review of the literature concerned or to describe the details of the technique.

However, even to-day, two questions have been left unsolved with regard to the 'vital staining': 1 . How is the stain ingested into cell from the surrounding tissue fluid? 2. How become visible in the cytoplasm the dye granules that have been ingested as ultra-microscopic particles? There are two conflicting views concerning these questions ; the one is from the chemical and the other from the physical standpoint. Those who insist on the physical theory such as Höber, Schule- 
mann, Evans have studied the physical process of the staining only from the side of dye, without considering the physical condition of the cells. But it can not be doubted that beside the diffusibility of the stain the density of the cells plays an important rôle in the staining. So in the present paper I shall discuss in some detail the influence of the cell density and of the diffusibility of the stain on the 'vital staining'.

\section{Historical.}

Fischel's statement (1901) that only the basic stains are taken up by the living cells is contradicted by the striking results obtained from staining in vivo with pyrrol blue, trypan blue and other acid stains. The lipoir theory of 'vital staining', brought forward by Overton (1900), has also been proved to be inadequate by Ehrlich and Goldmann (1900), in view of the fact that some dozen stains, which are insoluble in lipoids, also enter the living cells.

According to the chemical theory advanced by Ehrlich (1904-09), the stain is taken up by the cell body in virtue of a certain chemical process and the 'vital staining' is nothing but a true chemical combination of a part of the stain molecule and a side-chain of the cell, known as chemo-receptor. Höber (1909) states, on the contrary, that the colloidal dyes, such as trypan blue and lithium carmine, are taken into the cells by a process corresponding to phagocytosis and are lodged in the form of chemically unchanged granules in the cytoplasmic racuoles of certain types of cells.

Schulemann in his ealier view (1922), Goldmann (1912), Pappenheim and Nakano (1913), and Taschaschin (1913) believe that the staining granules present a combination of the dye with some reacting ingredients in the cell, such as plasmosomes, secretory granules, etc.

Taschaschin believes that the fine granules and rods in the fibroblasts and the small blue granules of clasmatocytes seen after pyrrol blue injection are chondriosomes, while the larger round granules after the same treatment are secretory granules derived from the chondriosomes. Gross (1911-14) is of opinion that the stained granules in the cell may change their size and stainability according to the secretory phases of the cell. Scott (1915), however, has shown that the chondriosomes of these cells may be stained by Janus green in opposition to the blue granules. She could find no relation between the latter and the chondriosomes. Kiyono (1914) states that an active function of living cell similar to phagocytosis plays an importaht rôle in the ingestion of 
the dye, and that the dye combines with some preformed protoplasmic granules which are capable of precipitating the dye in themselves. He calls these granules 'chromophile granules' to distinguish them from others.

Schulemann and Evans (1914-15) and Downey (1917-18) strongly advocate that the stained granules are merely aggregations of the dye particles taken up by a process similar to phagocytosis and deposited within the cytoplasmic vocuoles, without combining with any constituent of the cell. In other words, the formation of the stained granules is a physical process, and not a chemical one such as a combination of the receptor of the cell with the dye.

\section{Technique.}

In my experiments it was aimed to examine how the stain is ingested into the living cells when the density of cell body is altered by the injection of potassium or calcium compounds.

For this purpose several salts and bases of potassium and calcium together with various acid and basic stains of different diffusibilities were used.

The compounds of potassium and calcium were dissolved in water in the ratio of 1 per cent, except $\mathrm{KOH}$ and $\mathrm{Ca}(\mathrm{OH})_{2}$, the former of which was made to a dilute aqueous solution in accordance with the lime water employed as a $\mathrm{Ca}(\mathrm{OH})_{2}$ solution. To the above solutions stain was added 2 per cent and was injected to the ear vein of rabbit. The first injection was $4 \mathrm{cc}$ per kilo body weight. Injections were repeated once a day, each with a 1 ce increase per kilo body weight.

24 hours after the last injection the rabbit was killed by air emboly. The kidney, liver and spleen were taken out as fast as possible and were fixed in 10 per cent formalin solution. Paraffin sections of $5 \mu$ thickness were made. Counterstain was used.

\section{Experimental.}

A. Trypan blue, carmine, tolidin blue and neutral red.

These stains are generally used for the purpose of vital staining, because they, if injected, are taken up without exception by the cell body of certain kinds of cells in the form of granules. In a single injection the dye granules are usually very small both in size and in number. With the repeated injections they'grow larger and become more numerous. 
Trypan blue, tolidin blue and neutral red were used as aqueous solutions, -while carmine was injected in the form of lithium carmine. The results of vital staining has been so repeatedly reported by different authors, that it is hardly necessary to go into details, my results being nothing but a comfirmation of those of previous workers.

However mention should be made regarding the vital staining in conjunction with potassium and calcium compounds.

\section{Potassium compounds.}

If the stain dissolved in a solution of potassium compounds such as $\mathrm{KCL}, \mathrm{KOH}, \mathrm{KBr}, \mathrm{KC}_{2} \mathrm{H}_{3} \mathrm{O}_{2}, \mathrm{KNO}_{2}, \mathrm{~K}_{2} \mathrm{SO}_{4}$ is injected, the tissue elements become looser, the cells being somewhat swollen. At the same time the stain is taken up by the cells far in greater quantity and is seen in the cell body in the form of much larger granules as compared with the case of the usual vital staining. This difference becomes more and more conspicuous with the repetition of injections.

The kidney: The lumen of the renal tubules becomes narrow on account of the swelling of the epithelial cells, and contains sometimes the dye granules. In the distal convoluted portion of the tubules the stain is deposited no less than in the proximal segments of the tubules, where the large round dye granules are often arranged in the form of radial striations which occupy the cell basis, reaching the level of, or a little above, the nucleus. The dye granules are also seen in the glomerular capsules and in the beginning of the straight collective tubules, though small both in size and in number.

The liver: Kupffer's stellate cells, the histiccytes (Kiyono and Aschoff) in the interlobular connective tissue and the liver parenchym cells are all structurally more or less loosened, and in most cases contain the stain abundantly; in the stellate cells and histiocytes the dye granules are round and of various sizes, in the parenchym cells they are found around the nuclei, and are rodlike or irregularly shaped.

Spleen: The endothelial cells of the venous sinus, the reticuloendothelial cells of the splenic pulp and the splenocytes (classified as macrophages) usually contain the large stain granules in great quantity. Besides, the stain granules are well visible in the reticuloendothelial cells of the splenic corpuscle, which scarcely take up the stain, when vitally stained in the usual manner.

2. Calcium compounds.

If the stain dissolved in a solution of calcium compound such as 
$\mathrm{CaCL}_{2}, \mathrm{Ca}(\mathrm{OH})_{2}, \mathrm{Ca}(\mathrm{Br})_{2} \mathrm{Ca}\left(\mathrm{C}_{2} \mathrm{H}_{3} \mathrm{O}_{2}\right)_{2}, \mathrm{Ca}\left(\mathrm{NO}_{3}\right)_{2}, \mathrm{CaSO}_{4}$ is injected, the tissue elements become more or less condensed and the cells shrink. The stain granules found in the cell body are very small and scanty. Comparison with the finding' in the case of the usual vital staining gives

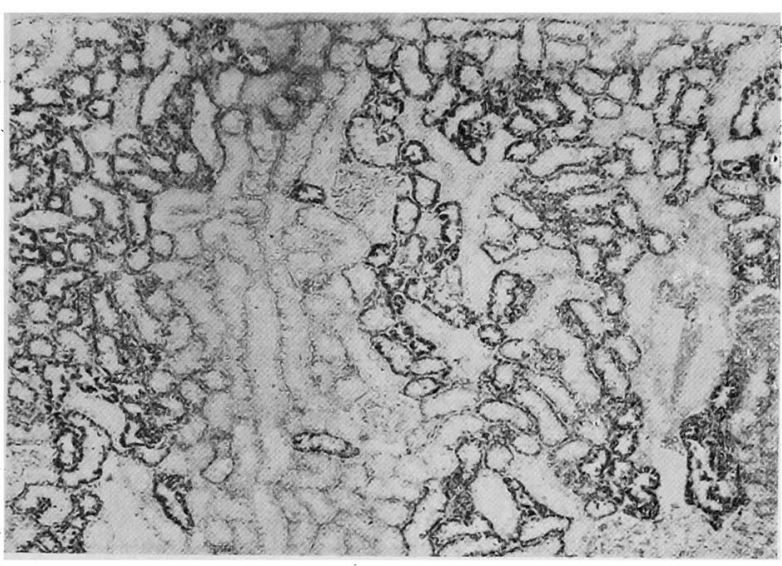

Fig. 1. A.

Fig. 1. Iongitudinal sections through renal tubules of rabbits which received injections of $2 \%$ tolidin blue for 5 days. $5 \mu$ paraffin section. Fixed in formalin and counterstained with Bismark brown. A. Simple Tolidin blue solution injection, showing medium storage of the stain granules in the cells.

only a few reaching the level of the cell nuclei. In the distal convoluted portion of the tubules the epithelial cells are free from the stain or contain only a trace of it near the cell basis. In the glomerular capsules and the straight collective tubules there is no trace of the stain.

The liver and Spleen : Generally structural shrinkage of the cells is seen, which is always accompanied an impression that the entrance of the stain has been checked by the condensation of the cell.

The kidney: Because of the shrinkage of the epithelial cells, the lumen of the renal tubules. is enlarged and does not contain the stain at all. In the proximal convoluted portion of the tubules the dye granules are arranged along the basal striations of the cells, but they are small in size and in quantity,

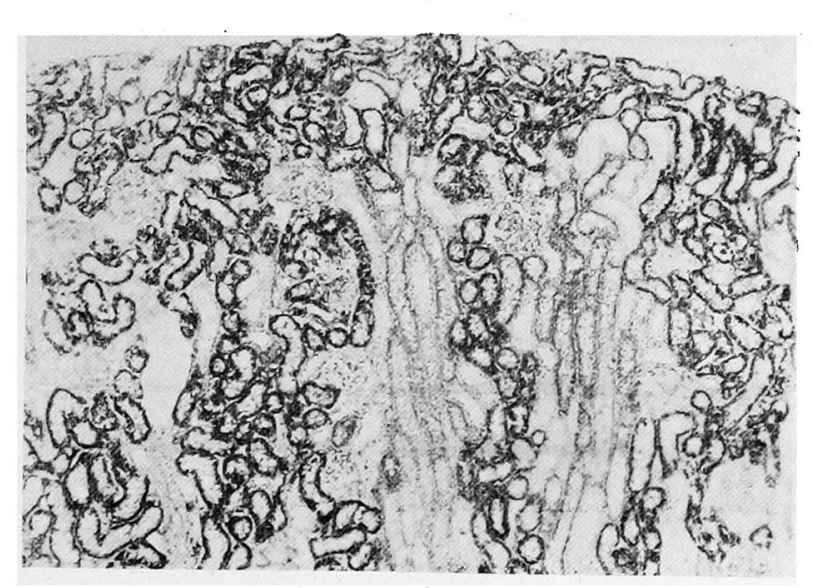

Fig. 1. B.

Tolidin blue $+1 \%$ potassium chloride solution, showing loose and swollen cells, containing a large amount of of stain granules. : 
by a reduction of the taking up of the stain. Especially in the reticuloendothelial cells of the splenic pulps no trace of the stain is detectable.

B. India ink.

According to the prevalent opinion india ink can only be taken up

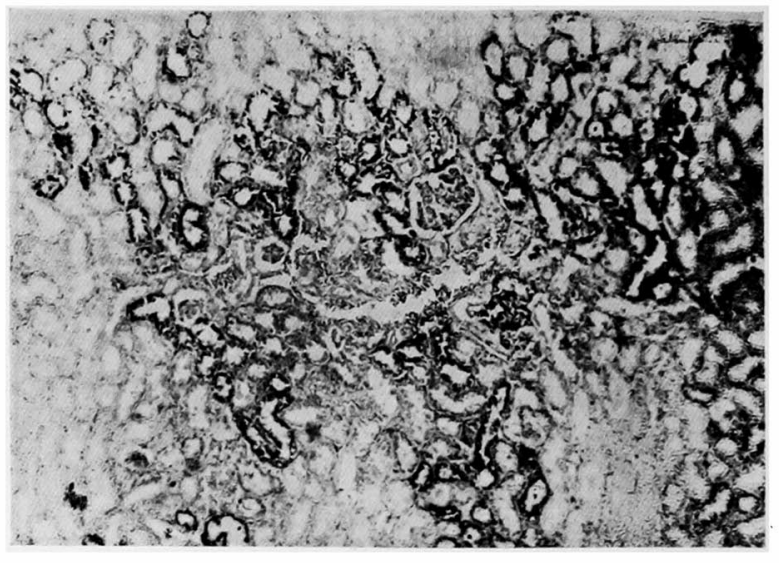

Fig. 1. C.

Tolidin blue $+1 \%$ calcium chloride solution, showing condensed and shrunken cells with a few stain granules. by the cells endowed with an activity identical with phagocytosis. And this is true, if the vital staining is carried on in the ordinary way.

\section{Potassium compounds.}

India ink mixed with a potassium solution was repeatedly injected. It was ingested abundantly by all the phagocytes. Comparison with the find-

ings in the vital staining without any potassium compound shows that india ink is taken more as larger granules.

The kidney : The tissue elements are evidently swollen, but india ink granules are not found in the epithelial cells of the renal tubules, only the wandering histiocytes in the gromelular capsules and those in the connective tissue containing them.

The liver: The

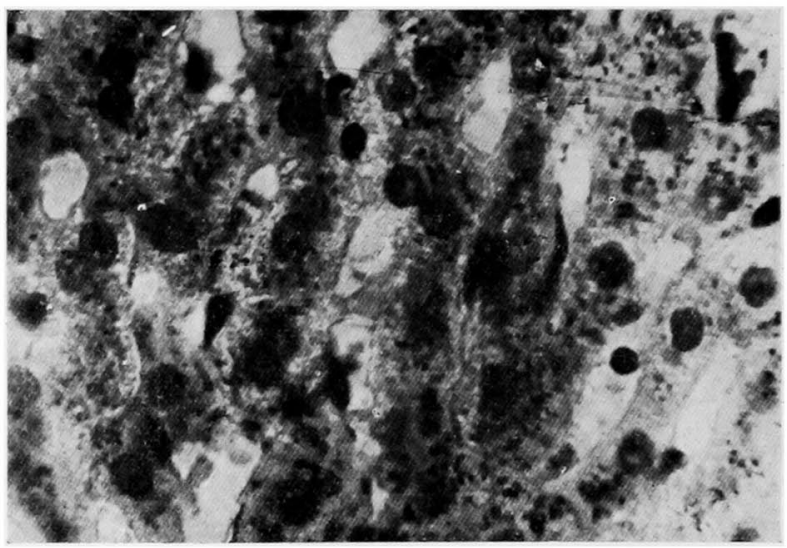

Fig. 2. A.

Fig. 2. Sections through liver of rabbits in which injections of $2 \%$ carmine were repeated for 5 days. $5 \mu$ paraffin section. Fixed in formalin; counterstained with Hausen's haematoxylin. A. Carmine was used with saturated lithium carbonate solution. Showing medium storage of stain granules in cells. 
stellate cells and the histiocytes of the interlobular connective tissue are swollen each taking the form of an ellipse or a sphere, and contain numerous large and small granules of the india ink. But what aroused particularly my interest is the fact, that the parenchym cells also took up india ink though in small quantity and as small granules, for the cells do not take up india ink at all in the case of the ordinary vital staining.

The spleen: In the endothelial cells of the splenic pulps and in

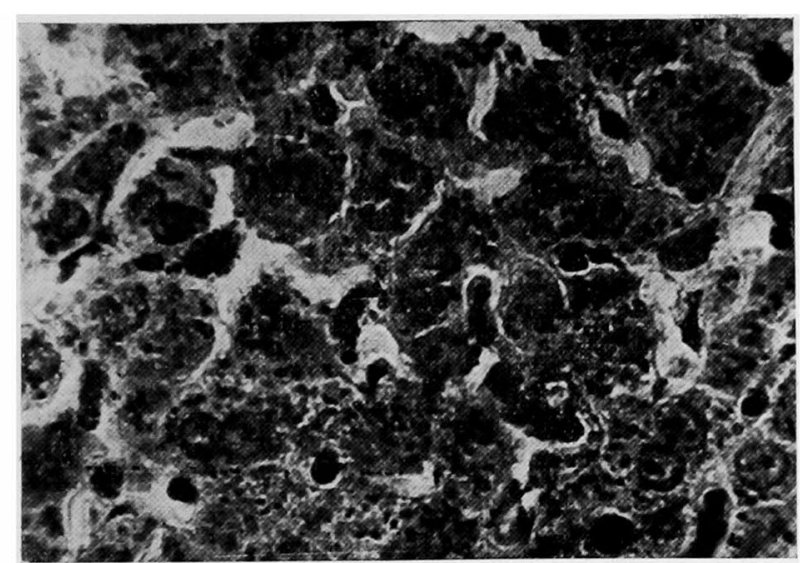

Fig. 2. B.

Stain was used with dilute potassium hydrate solution. Showing loose and swollen cells with many stain granules. the splenocytes india ink appears in the form of large granular masses. Even in the reticuloendothelial cells of the splenic corpuscles the trace of its granules is perceptible.

\section{Calcium com- pounds.}

If india ink mixed with a calcium solution is injected, the tissue elements become condensed and the india ink is not taken up by

such cells as the liver parenchym cells and the reticulo-endothelial cells of the splenic pulp contrary to the case, where a potassium compound is used. Moreover the granular masses ingested in the phagocytes are rare and small in comparison with the cases whien india ink is used with distilled water or with normal saline solution.

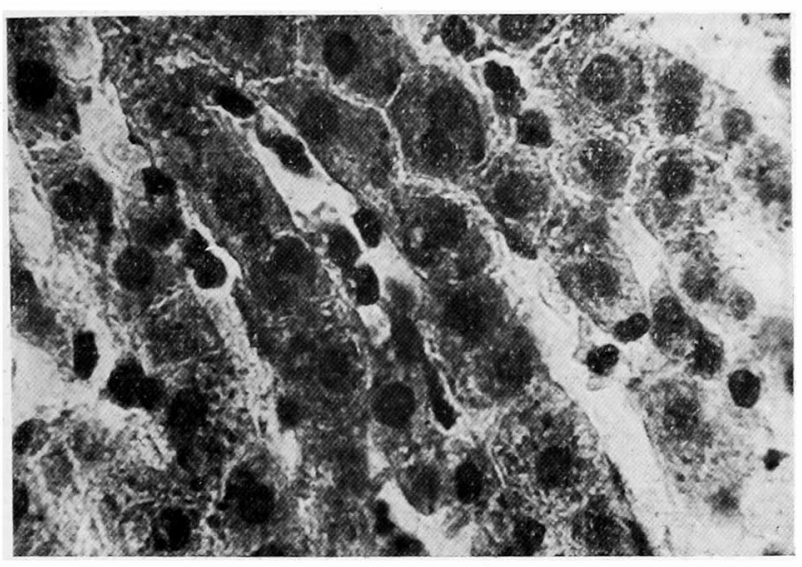

Fig. 2. C.

Stain was used with lime water. Showing condensed and shrunken cells with a few stain granules. 


\section{Acid fuchsin, eosin, orange yellow.}

These stains are very diffusible and generally looked upon as unfit for vital staining, because they do not deposit in the cell in the form of visible granules, even if they are repeatedly injected.

But I experienced that the epithelial cells of the convoluted portion of the renal tubules, the parenchym cells of liver, the reticulo-endothelial cells of the splenic pulp, etc. can be stained faintly and diffuse by any of these stains, if repeatedly injected. Potassium compound makes these dyes stain more faintly, while calcium compound more marked.

\section{Comments.}

In all the cases, in which such compounds of potassium and calcium as chloride, hydrate, bromide, acetate, nitrite and sulphate are used, it has been prover that potassium and calcium act antagonistically upon the density of the tissue, and that the result of the vital staining depends on the diffusibility of the stain, irrespective of the acid or basic nature of the stain.

Those stains which are generally employed for vital staining and are not highly diffusible give a better result, if they are injected together with potassium compounds; the cell body being loosened and stain granules being larger and numerous as compared with the case of the usual vital staining. On the contrary calcium compounds make the rital staining less distinct, the cell body being condensed and less stain being taken. We meet with different results with such diffusible stains as acid fuchsin, eosin and orange yellow. They are better retained in the cell body, condensed by calcium compounds, while they readily escape from the cell body subjected to the action of potassium compounds.

Antagonistic actions of potassium and calcium compounds can readily be seen after a few injections, but they become more frappant after many injections.

Some stains such as trypan blue and tolidin blue consist of two constituents, which are different in color and diffusibility, namely a red highly diffusible and a blue less diffusible substance. It is of particular interest that if such a dye is injected together with potassium compounds the color of stain granules appearing in the cell body ranges from bright blue to blue black. If such a stain is used with calcium compounds, it varies from violet to violet red.

It should be noted that the antagonistic action of potassium and 
calcium depends upon cations and not upon anions. The metal ions having an electric charge opposite to that of the protoplasma tend to coagulate the latter, but they are covered with a water hull, so that the cell body must swell by dydration, if some metal ions enter it. K-ions readily cause the swelling of the tissue elements, since they can freely enter the cell, owing to their thin water hull and to their great migration velosity. Ca-ions, however, can not enter the cell easily ; for each of them has a thick water hull and a small migration velocity. They, therefore, remain outside of the cell for a long time, and thereby withdraw water from the cell making the cell denser. This, I believe, seems to be an adequate explanation to account for the antagonistic action of potassium and calcium upon the density of the tissue elements.

As a rule, the dye granules which appear in the cell body after a few injections are minute and are not many, but they increase both in size and number with the repetition of injections. This seems to indicate that the stain at first is taken up by the cell as ultra-microscopic particles, which later aggregate to form visible granules, as more injections are performed.

The reason why india ink is usually taken up only by the phagocytes as visible granules even after a single injection, and why some cells which possess no power of phagocytosis like the liver parenchym cells can take up india ink, if it is injected with potassium compound, is due to the fact that india ink contains soot particles in solution, which are too large to be ingested by any cells excepting the phagocytes. However these particles can penetrate the non-phagocytic cells, if the latter are loosened by potassium compounds.

It should here be stated that the diffusibility of the stain depends chiefly on the size of the stain particles in its aqueous solution. Aqueous solutions of some stains such as trypan blue, carmine, tolidin blue and neutral red contain larger stain particles that diffuse very slowly. Such stains can readily enter the cell body only when the latter is loose, as this is the case after the injection of potassium compounds. But if once the stain has entered the cell body it does not easily escape even in the case where the cell structure is loose. On the contrary other stains such as acid fuchsin, eosin, orange yellow, etc. are dissolved almost as molecules in their aqueous solutions, and are, therefore, highly diffusible. Consequently they can enter the cell body very easily, but they do not build there visible granules. Moreover they can better be retained in the cell body, if the cell is made denser after the injection of calcium compound. On the other hand they go out from the cell body very 
easily, if the cell structure is loose. This is, I think, the reason why they do not stain the cell, if they are injected with potassium compound. Trypan blue and tolidin blue when used with potassium compound appear in the cell as vivid blue or blue black granules, while violet or violet red granules are seen in the cell body if the stains are used with calcium compound. This fact seems to give a further evidence in favor of the above mentioned explanation.

\section{Summary.}

1. Potassium compounds injected into the animal loosen the tissue elements, while calcium compounds condense them. Antagonistic effect between these two compounds is due to the nature of potassium- and calcium-ions.

2. Vital staining is caused by dye particles which have been taken up in the cell body by a physical process rather than a chemical one. Therefore the density of tissue elements and the diffusibility of the stain used play the most important rôle in the staining.

3. The loose cells take up the stain easily, while the dense cells do with difficulty, provided that the stain is not highly diffusible. The cells loosened by potassium compounds take up more stain than the normal cells. Calcium compounds on the contrary, hinder the entrance of the stain into the cell body, making the cell structure denser. Cells which refuse to be stained in the ordinary vital staining can be made to take color if potassium compounds are used with the stain. Sometimes just the opposite result is obtained by the use of calcium compounds.

4. Less diffusible stains always appear as visible granules in the cell body in the vital staining, while those of higher diffusibility are housed in the cell body without precipitating visible granules, so that the cells appear to be stained diffuse.

5. Such dyes which stain the cell diffuse escape from it easily, especially when it is loosened. The staining, therefore, is weakened by potassium compounds and maintained by calcium compounds - just opposite to the case, when a stain of low diffusibility is used.

6. Less diffusible stains do not appear in the cell body as coarse granules from the beginning; the granules at first are very fine. After repeated injections they gradually grow into larger granules by aggregation.

7. Potassium compounds help phagocytosis, while calcium compounds hinder it. 


\section{Bibliography.}

Anitschkow. Über vitale Färbung u. Cholesterinspeicherung. Med. Klinik. Nr. 11. 1914.

Arnold. Über Granulafärbung lebender u. überlebender Gewebe. Virchow's Archiv. Bd. 159. 1899.

Arnold. Bemerkungen über intravitale u. postvitale Granulafärbung. Zentralblatt f. allg. Path. u. patholog. Anat. Bd. 24. 1913.

Aschoff und Kiyono. Zur Frage der Grossen Mono. Folia haematologica. Bd. 15. Archiv 1913.

Basler. Über Ausscheidung u. Resorption in der Niere. Pflüger's Archiv. Bd. 112. 1906.

Downey. Reaction of blood- and tissue cells to acid colloidal dyes under experimental conditions. Anat. Record. Vol. 12. 1917.

Downey. Further studies on the reaction of blood- and tissue cells to acid colloidal dyes. Anat. Record. Vol. 15. 1918.

Evans, Schulemann und Wilborn. Die vitale Färbung mit sauren Farbstoffen in ihrer Bedeutung für pharmakologische Probleme. Deutsch. med. Wochenschr. 40 Jahrung. 1914.

Fischel. Untersuchung über vitale Färbung. Anat. Hefte. 1901. Heft 52/53.

Goldmann. Vitale Färbung und Chemotherapie. Berlin. Klin. Wochenschr. 1911. Nr. 36.

Gross. Über den Zusammenhang zwischen Farbstoffausscheidung und vitale Färbung der Niere. Verhandl. der Deutsch. pathol. Geselschaft. 17 Tagung. 1914.

Höber. Die Durchlässigkeit der Zellen für Farbstoffe. Biochemisch. Zeitschr. Bd. 20. 1909.

Höber und Königsberg. Farbstoffausscheidung durch die Niere. Pfläger's Archiv Bd. 108. 1905.

Kiy ono. Studies on the vital staining. 1929. Tokyo.

Loele. Über vitale Granulafärbung mit sauren Farbstoffen. Folia haematologica. Bd. 14. 1913.

Möllendorf. Die Dispersität der Farbstoffe: ihre Beziehung zu Ausscheidung u. Speicherung in die Niere. Anat. Hefte. Bd. 53. 1915.

Pappenheim und Nakano. Beiträge über die Beziehungen zwischen Vitalfärbung, Supravitalfärbung und Oxydasereaction. Folia haematologica. Bd. 14. 1912.

Ribbert. Die Ausscheidung intravenös injizierten gelösten Karmins in den Geweben. Zeitschr. f. allg. Physiologie. Bd. 1. 1904.

Schulemann. Beiträge zur Vitalfärbung. Archiv. f. mikr. Anat. Bd. 79. 1912.

Scott. The relation of mitochondria to granules of the vital azo dyes. Science, Med. series. Vol. 41. No. 1966.

Taschaschin. Über vitale Färbung der Chondriosomen in Bindegewebszellen mit Tryp̀anblau. Folia haematologica. Bd. 14. 1912. 